\title{
After the fact-the case of CRISPR babies
}

\author{
Martin Sand $\mathbb{D}^{1} \cdot$ Annelien L. Bredenoord ${ }^{2} \cdot$ Karin R. Jongsma $\mathbb{D}^{2}$
}

Received: 28 December 2018 / Revised: 6 June 2019 / Accepted: 11 June 2019 / Published online: 24 June 2019

(c) European Society of Human Genetics 2019

\begin{abstract}
The world has been startled by the irresponsible experiment of He Jiankui, who used CRISPR to genetically modify human embryos. In this viewpoint, we explore the phenomenon of moral luck in medicine and its bearing on the limits of simple judgements of the kind "everything that ends well is well" or "someone broke the rules, and is therefore blameworthy". The risks involved in scientific and medical experiments are often brushed aside, when they turn out well. The clinical application of CRISPR in the human germline is presently too risky to be used without more preclinical research and unacceptable without broader societal support, which justifies the call for a moratorium by the scientific community. However, such policies do not determine how to assess cases, where someone was willing to take such risks beyond all rules, guidelines and regulation and succeeds. The policies including the proposed moratorium are as unanimous about the undesirability of current applications of clinical germline editing as they are about the potential importance of this research. What if this potential is achieved by breaking the rules? The paradox of moral luck impinges on this debate. In our analysis, we rebut simplified judgments and advocate a more balanced view on the relation between moral responsibility and the societal consequences of medicine.
\end{abstract}

\section{Introduction}

The world has reacted with shock and indignation to the news that He Jiankui of the Southern University of Science and Technology in Shenzhen, China, claimed to have used CRISPR-CAS to genetically modify human embryos, purportedly resulting in the recent birth of genetically altered twin girls [1]. He presented his work as a fait accompli, while the prevailing academic and political consensus remains that it is not yet safe nor desirable without global public discussion to start testing germline editing technologies on humans given the uncertain long-term effects, e.g. on the genetic make-up of future generations. Amongst others, the European Society for Human Genetics [2] endorses the plea of Lander et al. [3] for an international moratorium on clinical germline editing, which demands "that each nation should voluntarily pledge not to allow any application of germline editing unless certain requirements are met." While reproductive medicine has a

Martin Sand

m.sand@tudelft.nl

1 Technical University Delft, H2020 Marie Sklodowska-Curie Actions (707404), Delft, The Netherlands

2 University Medical Center Utrecht, Utrecht, The Netherlands history of introducing innovations into clinical practice without proper preclinical research into their effectiveness and safety, such as embryo and oocyte preservation, none of these techniques were as controversial as germline modification [4]. Because of the risks and the socio-political disapproval of engaging in germline editing without global consensus on a proper conditional framework, the commentators have predominantly argued that his experiment was unlawful and irresponsible [5, 6]. He is currently suspended for unethical behaviour and the violation of Chinese laws and an investigation is running against him [7].

Obviously, we cannot predict with certainty what the outcome of these clinical germline experiments will be. As the CRISPR babies were revealed after the fact, we cannot but hope that the girls turn out to be fine. While He undeniably violated established norms in bioethics, biomedical regulations and international laws, chances are that he has changed the babies' DNA successfully in terms of protection against HIV infection without harmful side effects. If the experiments turn out to be successful in the long run and open up new pathways to treat inheritable genetic diseases, He can consider himself lucky. It would mean that the work translates "advancements in human genetics into a benefit for patients" despite having disregarded established international consensus, policies and laws [2]. If these experiments thus became the first in a chain of preclinical and clinical 
experiments which are undertaken in a well-defined ethical and scientific framework, leading to a clinical revolution, his moral reprehensibility for breaking the rules, putting the girls at risk and disregarding the possible impact on the human germline might eventually be brushed aside. Such change of perception due to factors beyond control would be highly paradoxical, but not unprecedented. It would not be the first time in medical history that a high-risk and controversial endeavour is put in a different light because of its outcome, even if this very outcome was beyond the scientist's control. This paradox, discussed in philosophy as moral luck, seems to occur in various scientific disciplines including medicine. Moral luck means that factors beyond one's control affect how much praise or blame one receives [8, 9]. In other words: Moral luck affects moral responsibility. This is paradoxical, because we commonly deem people responsible only for factors within their control. Being responsible means being worthy of praise or blame. In this manner, moral luck also poses a fundamental challenge for the legitimacy of sanctions and rewards, which are important elements of science policy. Such practices aim at discouraging wrongdoings both by the perpetrator and potential imitators: Expressing blame is a way of showing societal discord with certain behaviour, which rests essentially on convictions about people's moral responsibility [10]. By observing the CRISPR-case real-time, we may learn important lessons about the significance of moral luck in science and its implications for science policy.

\section{Discussion}

While his case is unique in disregarding the risk to the species, one will easily find analogous examples in medicine, where considerable risks have been imposed on persons that were then underrated in hindsight. A prominent analogy to the CRISPR babies' case in terms of potential moral luck can be found in the history of vaccination. This analogy may help to get a better grip of how the paradox of moral luck has a foothold in medicine. Edward Jenner was morally lucky when on May $14^{\text {th }} 1796$, he performed "his first vaccination, introducing material from a cowpox vesicle of Sarah Nelmes, a milkmaid, into the arm of a boy named James Phipps." [11] A few weeks later, he continued this risky procedure by inoculating the boy with the smallpox virus, which was at the time highly lethal. The eight-year old luckily survived the procedure with little to no harm. In hindsight, this experiment is seen as a crucial step towards the establishment of vaccination, now widely considered a medical revolution that led to the global eradication of the smallpox $[12,13]$. Vaccination was far from being commonly approved at the time and the prevailing resistance even after Jenner's experiments, suggests that one could entertain reasonable doubts about its prospects [14]. When Jenner inoculated James Phipps with smallpox, he was led by little more than intuition and rumours. Surely, he could not have been certain that the procedure would be successful. Given the enormous success of vaccination, few authors today find it reproachable that Jenner put the life of a boy at risk based on a hunch and poor evidence [15], despite the serious possibility of failure at the time. Up until today, historians wonder with good reason, how he "persuaded the boy and his parents to take such a chance." [16] History has given him right, or so it seems [8]. Nowadays, Jenner supposedly deserves to be called a medical "hero" [11], and his "life story remains an inspiration to physicians." [17] To regard Jenner as worthy of praise is to consider him morally (co-)responsible for the success of vaccination. In contrast, Jenner's legacy would be very different, if not forgotten, had James Phipps died during the procedure and had the idea of vaccination turned out to be a fatal illusion. Jenner's case does not only illustrate that luck plays a role in medical experiments, but also that moral luck-Jenner is praised for an outcome that he did not control-prevails.

His case is in such a way analogous to Jenner's that the success of his experiments and their side effects are highly uncertain and elude his ultimate control, making it a case of potential moral luck. Even though Jenner might not have crossed established ethics consensus, laws and regulations as obviously as He did, medicine in Jenner's century was not an "ethical wild West" either. Many of his contemporaries such as Thomas Percival and John Gregory promoted medical ethical debates and demanded a high level of moral sensitivity from doctors [18, 19]. Even if it is never easy to judge the significance and scope of ethical values of a former historical epoch, one can without doubt say that such standards existed. The scientific community is obviously worried about the wellbeing of the twin girls, as it is not clear what (long-term) effects the gene alterations with CRISPR will have and whether the modification will be successful to prevent infections. Recent research suggests that his intervention has likely also altered the girls' brains [20, 21]. At the individual level the girls should be monitored very closely, as they may develop serious health conditions. At the human species level, his experiments entail an array of possible consequences for future generations through germline modifications. Nobody, including $\mathrm{He}$, can foretell the effects of human germline editing let alone the wider social consequences of this technology once it becomes more widely used. The immediate public and academic reaction shows that his reckless experiment has harmed the trust in genome editing technologies, which is just one of a number of its possible broader societal consequences. If after extensive global consensus finding, a first-in-human germline gene editing trial is considered 
ethically justified, it should be set up in accordance with broadly accepted international research ethics requirements and due diligence, not as a stand-alone experiment. Nevertheless, any subsequent success or failure of the current experiment may have an impact on our long-term view on his moral responsibility: Paradoxically, his reputation may still change synchronous with the advancement of genome editing. The recklessness of the original act might gradually dissolve from public memory and He may then become morally lucky, something currently unimaginable after the widely carried criticism of his crossing of legal and ethical boundaries. The alternative to this paradoxical view, the adherence to a luck-free concept of responsibility to underpin science policy, would mean that scientists are responsible only for things they ultimately control. According to such notion of responsibility, the outcome of the experiment will not determine the ascription of praise or blame [22]. This also means that harmful outcomes of the experiment such as those currently alerting academics and the public, would not affect his moral responsibility: $\mathrm{He}$ would (simply) remain a reckless risk-taker and not someone who is responsible for a technological catastrophe. This concept of responsibility leaves scientists very little except their volitions to be responsible for, which is not more intuitive either: Are we not reasonably grateful to Jenner for having received the benefits of vaccination? Shall we instead perpetuate a resentful image of him as a risk-taker and remove the advantages of vaccination from his moral record? A medical hero, as popular opinion suggests, Jenner would be no more.

\section{Conclusion}

The paradox of moral luck goes deep and concerns policy makers and the general public just as much as it has been troubling ethicists for several decades. Many established science policies comprise overt blame as a form of sanction, which is also starkly present in current commentaries on the case [5, 6]. However, as history tells us, the quality of actions alter in the light of their consequences. This exposes the fallibility of simple judgements of the kind "all that ends well is well" or "people who broke the rules are blameworthy." Moral luck confronts policy makers with puzzling question to which there is no satisfactory answer: Should consequences affect scientists' responsibility? If consequences, which are beyond their control do play a role, some scientists might never receive overt praise, because diligent effort does not necessarily lead to achievements. If, on the other hand, such consequences play no role for moral responsibility, then Jenner's standing will have to be reduced to that of a reckless trailblazer despite his contribution to the eradication of a dreadful disease.
Either solution is unsatisfactory. Moral luck transcends the ascription of moral responsibility: Scientists build their reputation based on merits and achievements, which are to some extent beyond their control. Thus, also practices of rewarding outstanding scientific achievements (e.g. Nobel Prizes) bear essentially on convictions about scientists' moral responsibility. This might be affected by how things turn out during and after scientific experiments, which is ultimately not within their control. While everyone is hoping that imitators are discouraged by the public resentment and that the CRISPR-babies grow up healthily, the complex debate about the implications of luck for his responsibility and the appropriate policy responses still lies ahead.

Funding Martin Sand's contribution to this paper has been funded by the European Union's Horizon 2020 research and innovation programme under the Marie Skłodowska-Curie grant agreement No 707404

\section{Compliance with ethical standards}

Conflict of interest The authors declare no conflict of interest.

Publisher's note: Springer Nature remains neutral with regard to jurisdictional claims in published maps and institutional affiliations.

\section{References}

1. Normile D. Shock greets claim of CRISPR-edited babies. Science. 2018;362:978-9. https://doi.org/10.1126/science.362.6418.978.

2. European Society for Human Genetics. Response to "Adopt a moratorium on heritable gene editing". European Society for Human Genetics; 2019. https://www.eshg.org/index.php?id=909. Accessed 18 Apr 2019.

3. Lander ES, Baylis F, Zhang F, Charpentier E, Berg P, Bourgain C, et al. Adopt a moratorium on heritable genome editing. Nature. 2019;567:165-8. https://doi.org/10.1038/d41586-019-00726-5.

4. Bredenoord AL, Appleby JB. Mitochondrial replacement techniques: remaining ethical challenges. Cell Stem Cell. 2017;21:301-4. https://doi.org/10.1016/j.stem.2017.08.009.

5. Cyranoski D. CRISPR-baby scientist fails to satisfy critics. Nat News. 2018. https://doi.org/10.1038/d41586-018-07573-w.

6. Caplan A He Jiankui's Moral Mess [Community Blog]. PloS Biologue. 2018. https://blogs.plos.org/biologue/2018/12/03/he-jia nkuis-moral-mess/. Accessed 07 Dec 2018.

7. Wee S-L. China halts work by scientist who says he edited babies' genes. The New York Times; 2018. https://www.nytimes.com/ 2018/11/29/science/gene-editing-babies-china.html. Accessed 07 Dec 2018.

8. Williams B. Moral luck. Cambridge: Cambridge University Press; 1981. pp. 20-39.

9. Nagel T. Moral luck. Mortal questions. London: Cambridge University Press; 1991. pp. 24-38.

10. van de Poel I, Sand M. Varieties of responsibility - two problems of responsible innovation. Synthese. 2018. https://doi.org/10. 1007/s11229-018-01951-7.

11. Gross CP, Sepkowitz KA. The myth of the medical breakthrough: smallpox, vaccination, and Jenner reconsidered. Int J Infect Dis. 1998;3:54-60. 
12. Brickman JP. The Eradication of Smallpox. Edward Jenner and the First and Only Eradication of a Human Infectious Disease. J Public Health Policy. 2002;23:517-519. https://doi.org/10.2307/ 3343253.

13. Riedel S. Edward Jenner and the history of smallpox and vaccination. Proc (Bayl Univ Med Cent). 2005;18:21-5. PubMed PMID: 16200144.

14. Williams G. Angel of death: the story of smallpox. Basingstroke: Palgrave Macmillan; 2010.

15. Boylston AW. The myth of the milkmaid. New Engl J Med. 2018;378:414-5. https://doi.org/10.1056/NEJMp1715349. PubMed PMID: 29385360.

16. Roberts RM. Serendipity: accidental discoveries in science. New York: John Wiley \& Sons; 1989.

17. Willis NJ. Edward Jenner and the eradication of Smallpox. Scott Med J. 1997;42:118-21. https://doi.org/10.1177/003693309704200407. PubMed PMID: 9507590.
18. McCullough LB. John Gregory and the invention of professional medical ethics and the profession of medicine. Dordrecht: Kluwer Academic Publishers; 1998.

19. Truman JT. The compleat physician: John Gregory MD (1724-1773). J Med Biogr. 1995;3:63-70. https://doi.org/10. 1177/096777209500300201.

20. Joy MT, Ben Assayag E, Shabashov-Stone D, Liraz-Zaltsman S, Mazzitelli J, Arenas M, et al. CCR5 Is a therapeutic target for recovery after stroke and traumatic brain injury. Cell. 2019;176:1143-57. https://doi.org/10.1016/j.cell.2019.01.044.

21. Regaldo A. China's CRISPR twins might have had their brains inadvertently enhanced. MIT Technology Review. 2019. https://www.technologyreview.com/s/612997/the-crispr-twins-ha d-their-brains-altered. Accessed 02 Mar 2019.

22. Khoury AC. The objects of moral responsibility. Philosophical Studies. 2018;175:1357-81. https://doi.org/10.1007/s11098-0170914-5.12/28/2018. 